6 Laine L, Cook D. Endoscopic ligation compared with sclerotherapy for treatment of esophageal variceal bleeding. A meta-analysis Ann Intern Med 1995;123:280-7.

7 Goulis J, Burroughs AK. Portal hypertensive bleeding. In: McDonald J, Burroughs A, Feagan B, eds. Prevention and treatment in evidence based gastroenterology and hepatology. London: BMJ Publishing Group, 1999:389426.

8 D'Amico G, Pagliaro L, Bosch J. The treatment of portal hypertension: A meta-analytic review. Hepatology 1995;22:332-54.

9 Feu F, Garcia-Pagan JC, Bosch J, et al. Relation between portal pressure response to pharmacotherapy and risk of recurrent variceal haemorrhage in patients with cirrhosis. Lancet 1995; 346:1056.

10 Jalan R, Forrest EH, Stanley AJ, et al. A randomised trial comparing transjugular intrahepatic portosystemic stent-shunt with variceal band ligation in the prevention of rebleeding from oesophageal varices. Hepatology 1997;26: $1115-22$.

11 Cello JP, Ring EJ, Olcott EW, et al. Endoscopic sclerotherapy compared with percutaneous sclerotherapy compared with percutaneous transjugular intrahepatic portosystemic shun after initial sclerotherapy in patients with acute
variceal hemorrhage: A randomized, controlled variceal hemorrhage: A randomized, con

12 Russo MW, Zacks SL, Sandler RS, et al. Cost-effectiveness analysis of transjugular intrahepatic portsosystemic shunt (TIPS) versus endoscopic therapy for prevention of esophageal variceal bleeding. Hepatology 2000;31 358-63.

13 Meddi P, Merli M, Lionetti R, et al. Cost analysis for the prevention of variceal rebleeding: a portosystemic shunt and endoscopic scleroportosystemic shunt and endoscopic sclero-
therapy in a selected group of Italian cirrhotic patients. Hepatology 1999;29:1074-7.

14 Pomier-Layrargues G, Villeneuve JP, Deschênes $\mathrm{M}$, et al. Transjugular intrahepatic portosys$\mathrm{M}$, et al. Transjugular intrahepatic portosys-
temic shunt (TIPS) versus endoscopic variceal ligation in the treatment of variceal bleeding in cirrhotic patients: a comparative randomized clinical trial. Gut 2000;48:390-6.

15 Papatheodoridis GV, Goulis J, Leandro G, et al. Transjugular intrahepatic portosystemic shun compared with endoscopic treatment for prevention of variceal rebleeding: A meta-analysis Hepatology 1999;30:612-22.

16 Angelico M, Carli L, Piat C, et al. Isosorbide-5mononitrate versus propranolol in the prevention of first bleeding in cirrhosis. Gastroenterol ogy 1993;104:1460-5.

17 Angelico M, Carli L, Piat C, et al. Effects of isosorbide-5-mononitrate compared with propranolol on first bleeding and long-term survival in cirrhosis. Gastroenterology 1997;113: survival

18 Lui HF, Stanley AJ, Forrest EH, et al. Primary prophylaxis of variceal haemorrhage: A randomised controlled trial comparing band ligation, propranolol and isosorbide mononitrate. Hepatology 1999;30:318A.

19 Bernard B, Grange JD, Khac EN, et al Antibiotic prophylaxis for the prevention of bacterial infections in cirrhotic patients with gastrointestinal bleeding: a meta-analysis. Hepatology 1999;29:1655-61.

\section{Long term follow up of interferon responder children with chronic hepatitis $B$}

EdIToR,-We read Bortolotti et al's article (Gut 2000;46:715-18) reporting the long term effect of interferon (IFN) alpha in children with chronic hepatitis B (HBV). Briefly, a total of 107 children with chronic HBV who received IFN alpha for three or six months in two clinical trials were followed for a mean period of 69 months. In the first trial 19 and 20 cases received IFN alpha at a dose of 3 and $7.5 \mathrm{MU} / \mathrm{m}^{2}$ three times a week for six months, respectively. In the second trial 34 cases received lymphoblastoid IFN at a dose of $5 \mathrm{MU} / \mathrm{m}^{2}$ for 12 weeks and 30 cases received IFN at the same dose but preceded by a four week course of prednisolone. Response to treatment was defined as loss of hepatitis B e antigen (HBeAg) within 12 months after stopping treatment. A control group of 59 patients was also followed for a mean period

Table 1 Number (\%) of patients who cleared HBeAg at different times in the four treatment groups

\begin{tabular}{|c|c|c|c|c|c|}
\hline Time & $\begin{array}{l}\text { Group } 1 \\
(n=8)\end{array}$ & $\begin{array}{l}\text { Group } 2 \\
(n=34)\end{array}$ & $\begin{array}{l}\text { Group } 3 \\
(n=5)\end{array}$ & $\begin{array}{l}\text { Group } 4 \\
(n=12)\end{array}$ & $\begin{array}{l}\text { Total } \\
(n=59)\end{array}$ \\
\hline End of treatment & $6(75 \%)$ & $23(67.6 \%)$ & $3(60 \%)$ & $6(50 \%)$ & $38(64.5 \%)$ \\
\hline 12 months after stopping treatment & $6(75 \%)$ & $32(94.1 \%)$ & $5(100 \%)$ & $12(100 \%)$ & $17(28.8 \%)$ \\
\hline End of follow up & $8(100 \%)$ & $34(100 \%)$ & $5(100 \%)$ & $12(100 \%)$ & $59(100 \%)$ \\
\hline
\end{tabular}

Interferon alpha dosage and duration: group $1,10 \mathrm{MU} / \mathrm{m}^{2}$ three times a week for six months; group 2, $5 \mathrm{MU} / \mathrm{m}^{2}$ three times a week for six months; group $3,5 \mathrm{MU} / \mathrm{m}^{2}$ three times a week for 12 months; group 4 (non-responders to previous interferon alpha treatment), $10 \mathrm{MU} / \mathrm{m}^{2}$ three times a week for six months.

of 46 months without any therapy. Sixteen $(15 \%)$ treated children responded during therapy and $18(17 \%)$ during post-treatment follow up; 31 (29\%) non-responders lost HBeAg during subsequent years. The cumulative $\mathrm{HBeAg}$ clearance rates at five years were similar between treated patients $(60 \%)$ and controls (65\%). Loss of hepatitis B surface antigen (HBsAg) occurred in only four patients who responded during treatment.

We also wish to report on the long term follow up of 59 IFN responder children with chronic HBV (table 1).$^{1-3}$ At the beginning of IFN therapy, all children (44 males; $74.6 \%$ ) had abnormal or fluctuating transaminases for at least six months and were positive for HBV DNA. Mean age of the patients at diagnosis of chronic HBV was 6.8 (3.4) years (range 1-15). They were followed for a mean period of 19.9 (21.5) months (range 6-100) before treatment. Liver biopsy was performed on 29 patients; $15(51.7 \%)$ had mild, 12 $(41.4 \%)$ moderate, and two (6.9\%) severe hepatitis. Forty three $(84.3 \%)$ of 51 patients had at least one family member with positive HBV serology. Eight patients (group 1) had received IFN alpha at a dose of $10 \mathrm{MU} / \mathrm{m}^{2}$ three times a week for six months, ${ }^{1} 34$ (group 2) at a dose of $5 \mathrm{MU} / \mathrm{m}^{2}$ three times a week for six months ${ }^{2}$ or 12 months (five patients, group 3). Twelve patients (group 4) who were unresponsive to IFN therapy at a dose of $5 \mathrm{MU} / \mathrm{m}^{2}$ received IFN alpha again at a dose of $10 \mathrm{MU} / \mathrm{m}^{2}$ three times a week for six months. ${ }^{3}$ Response to treatment was defined as loss of HBeAg during the treatment period or within 12 months after stopping treatment. All patients were followed for a mean period of 35.3 (10.8) months (range 18-62) after starting treatment. Thirty eight (64.5\%) patients cleared $\mathrm{HBeAg}$ at the end of IFN therapy and $17(28.8 \%)$ within 12 months after stopping treatment. Four $(6.7 \%)$ patients were late responders $(\mathrm{HBeAg}$ clearance was observed between 21 and 30 months after stopping therapy). The mean period of HBeAg clearance was 8.2 (7.0) months. Within the follow up period, antibody to hepatitis B surface antigen (anti-HBs) occurred in seven $(18.4 \%)$ patients who responded during therapy and all but one lost HBsAg. After HBeAg clearance, anti-HBe seroconversion and loss of HBV DNA was observed in all patients. Alanine aminotransferase values normalised in $98.3 \%$ of patients. None had biochemical or serological relapse within the follow up period.

The majority of our patients cleared HBV DNA and HBeAg during therapy whereas only $15 \%$ of patients in the study of Bortolotti et al responded during therapy. They followed patients for an average of 69 months and observed that all IFN responders remained HBeAg and HBV DNA negative. Although our observation period was shorter than theirs, we also observed that all responders had sustained results at the end of follow up. Similar to Bortolotti et al's results, all HBsAg cleared patients were early responders to IFN therapy in our group. In conclusion, response to IFN alpha in children with chronic hepatitis $\mathrm{B}$ is permanent. It is necessary to follow these patients for longer periods to see the long term effects of IFN alpha therapy, such as prevention of cirrhosis and/or hepatocellular carcinoma.

N SALTIK H ÖZEN F GÜRAKAN A YÜCE

Department of Pediatrics, Gastroenterology Unit, Hacettepe University İhsan Doğramacl Children's Hospital, Ankara, Turkey

Correspondence to: Dr N Koçak, Hacettepe İhsan Doğramacı Çocuk Hastanesi, Gastroenteroloji Ünitesi, 06100 Ankara, Turkey. haozen@hacettepe.edu.tr

1 Gürakan F, Koçak N, Özen H, et al. Comparison of standard and high dosage recombinant interferon alpha $2 \mathrm{~b}$ for treatment of children with chronic hepatitis B infection. Pediatr Infect Dis $72000 ; 19: 52-6$.

2 Özen $\mathrm{H}$, Koçak N, Gürakan F, et al. Long-term follow-up of children with chronic hepatitis B follow-up of children with chronic hepatitis B
treated with interferon alpha $2 \mathrm{a}$. VIII International Symposium on Viral Hepatitis. Madrid, national Symposium on Viral Hepatitis. Madrid,

3 Ôzen H, Koçak N, Yüce A, et al. Retreatment with higher dose interferon alpha in children with chronic hepatitis B infection. Pediatr Infect Dis f 1999;18:694-7.

\section{Renal sodium handling in preascitic} cirrhosis

EDITOR,- - We read with interest the commentary by Clària and Rodés (Gut 1999;45:639) on our paper published in Gut which re-examined the mechanisms of renal sodium retention in patients with preascitic cirrhosis. ${ }^{1}$ In summary, in our patients we observed indirect evidence of expanded central vascular fluid volume compared with healthy controls and thought this physiopathological alteration was due to slightly reduced values of glomerular filtration rate (measured as creatinine clearance) and, mainly, to increased distal tubular retention of sodium when expressed as a fraction of the filtered sodium load that is reabsorbed by the distal nephron (26.9 (6.7)\% v 12.5 (3.4)\%, respectively; $\mathrm{p}<0.05)$.

Clària and Rodés advanced two criticisms and affirmed that our results, obtained by means of the lithium clearance and fractional excretion technique, may be influenced by two fundamental flaws. Firstly, the reliability of lithium clearance as a marker of distal fluid delivery in clinical conditions characterised by low fractional sodium excretion (below $0.40 \%$ ) has not been proved due to possible lithium reabsorption in the distal nephron. ${ }^{2}$ Secondly, in Clària and Rodés's opinion, our observation of more avid fractional sodium reabsorption by the distal nephron in compensated cirrhosis merely reflects diminished delivery of fluid and sodium to the distal segments (due to reduced glomerular filtration) rather than increased distal tubular sodium reabsorption. 
With reference to the first methodological remark, to our knowledge the value of fractional sodium excretion (FENa) below which lithium reabsorption beyond the proximal tubule occurs is $0.02 \%$ and not $0.4 \%$. $^{3}$ Obviously, our non-azotaemic preascitic cirrhotics displayed values of FENa well above this threshold $(0.76(0.39) \%){ }^{1}$

Concerning the second remark, although our patients displayed slightly lower values of creatinine clearance $(\mathrm{CCr})$ with respect to controls, the calculated deliveries of fluid and sodium to the distal nephron were not lower but somewhat higher, even if not significantly, than in healthy subjects (30.7 (9.3) $v 27.5$ (6.7) $\mathrm{ml} / \mathrm{min}$ and 4.25 (1.30) v 3.9 (1.0) $\mathrm{mEq} / \mathrm{min}$, respectively; all $\mathrm{p}>0.05) .{ }^{1}$ In effect, not surprisingly, we observed no correlation between values of $\mathrm{CCr}$ and distal delivery of fluid or sodium. ${ }^{1}$ Furthermore, because of the inverse correlation in the cirrhotic group between levels of plasma active renin and lithium clearance, we reaffirm a compensatory role for the proximal renal tubule as it seems capable of delivering more fluid and sodium to the loop of Henle during a progressive increase in circulating fluid volume, at least at this stage of disease. ${ }^{1}$

In conclusion, we agree with Clària and Rodés that some uncertainty may be introduced in studies assessing renal function in cirrhosis by measurement of glomerular filtration rate using creatinine clearance. However, we consider that our results on inappropriate avidity of sodium reabsorption by the distal nephron are relevant in explaining the already demonstrated increase in central fluid volume in patients with preascitic cirrhosis. $^{5}$

G SANSOÈ

Gastroenterology Unit, Gradenigo Hospital, Corso Regina Margherita 10, 10153 Torino, Italy

A FERRARI

Chair of Gastroenterology, Department of Internal Medicine, University of Modena, Modena, Italy

Correspondence to:

Dr G Sansoe. giovannisan@iol.it

1 Sansoè G, Ferrari A, Baraldi E, et al. Renal distal tubular handling of sodium in central fluid volume homoeostasis in preascitic cirrhosis. Gut 1999;45:750-5.

2 Kirchner KA. Lithium as a marker for proximal tubular delivery during low salt intake and diuretic infusion. Am F Physiol 1987;252:188-96.

3 Thomsen K, Olsen OV. Renal lithium clearance as a measure of the delivery of water and sodium from the proximal tubule in humans. Am F Med Sci 1984;288:158-61.

4 Boer WH, Koomans A, Dorhout Mees EJ, et al. Lithium clearance during variations in sodium Lithium clearance during variations in sodium intake in man: effects of sodium restriction a

5 Wong F, Liu P, Tobe S, et al. Central blood volume in cirrhosis: measurement with radionu-
clide angiography. Hepatology 1994;19:312-21.

\section{Reply}

Editor,- - In their letter, Sansoè and Ferrari make some excellent points on our accompanying commentary (Gut 1999;45:639) to their paper published in (Gut 1999;45:7505). In that paper, Sansoè et al investigated the status of central blood volume and examined the distribution of sodium reabsorption along the segments of the renal tubule in a group of 12 preascitic cirrhotic patients. Whereas the results on central fluid volume were quite conclusive, the findings on renal function merit some discussion (Gut 1999;45:639). As precisely pointed out by Sansoè and Ferrari in their letter, the contention was mainly methodological and was related to the use of lithium and creatinine clearances for determination of distal sodium reabsorption and glomerular filtration rate, respectively.

Lithium clearance is a useful marker of proximal tubule sodium handling because in theory this ion is reabsorbed in proportion to sodium and water along the entire proximal tubule. ${ }^{1}$ However, the validity of this method is not widely recognised. In this regard, there is compelling evidence that lithium is actively reabsorbed along the distal tubule in conditions characterised by low fractional sodium excretion. ${ }^{2}$ In healthy subjects, the estimated limit of fractional sodium excretion below which this problem arises has been established as $0.02 \%{ }^{3}$ Conversely, comprehensive studies of micropuncture have revealed that this value may vary from $0.4 \%$ to $0.65 \%$ in sodium depleted states. ${ }^{45}$ Finally, a value of fractional sodium excretion of $1 \%$ has been proposed as a safer limit by Koomans and colleagues. ${ }^{6}$ Thus, inasmuch as the value of fractional sodium excretion below which lithium clearance is disqualified as an index of proximal sodium delivery remains unresolved in cirrhosis, data derived from this method in cirrhotic patients should be interpreted with caution.

We should also point out that preascitic cirrhotic patients included in Sansoè et al's study (Gut 1999;45:750-5) had significantly lower values than controls for glomerular filtration rate, as determined by creatinine clearance. These findings are not consistent with those previously reported in compensated cirrhotics using more sensitive clearance techniques such as inulin clearance. ${ }^{7}$

In summary, it is gratifying to see that Sansoè and Ferrari agree that a certain amount of uncertainty may be introduced in studies dealing with renal function by using creatinine and lithium clearances. We believe that their paper will undoubtedly foster new studies investigating the central fluid volume status and renal tubular avidity for sodium in preascitic cirrhotic patients.

J CLÀRIA J RODÉS

Liver Unit, Institut d'Investigacions Biomèdiques August Pi I Sunyer (IDIBAPS) Hospital Clinic, Barcelona 08036, Spain

Correspondence to: Professor J Rodés, Liver Unit, Hospital Clinic, Villarroel 170, 08036 Barcelona, Spain.rodes@medicina.ub.es

1 Thomsen K. Lithium clearance: a new method for determining proximal and distal tubular reabsorption of sodium and water. Nephron 1984;37:217-23.

2 Thomsen K, Holstein-Rathlou N, Leyssac P. Comparison of three measures of proximal tubular reabsorption: lithium clearance, occlusion time and micropuncture. Am $\mathcal{F}$ Physiol sion time and mic

3 Boer WH, Koomans HA, Dorhout Mees EJ, et al. Lithium clearance during variations in sodium intake in man: effects of sodium restriction and amiloride. Eur $\mathcal{f}$ Clin Invest 1988;18:279-83.

4 Boer WH, Joles JA, Koomans HA, et al. Decreased lithium clearance due to tubular lithium reabsorption in sodium depleted dogs. Renal Physiol 1987;10:65-8.

5 Kirchner KA. Lithium as marker for proximal tubular delivery during low salt intake and diuretic infusion. Am f Physiol 1987;2:Fl88-96.

6 Koomans HA, Boer WH, Dorhout Mees EJ. Evaluation of lithium clearance as a marker of proximal tubule sodium handling. Kidney Int 1989;36:2-12

7 Ginès P, Rodés J. Clinical disorders of renal function in cirrhosis with ascites. In: Arroyo V, Schrier RW, Rodés J, et al, editors. Ascites and renal dysfunction in liver disease. Pathogenesis, diagnosis and treatment. Malden: Blackwell Science, 1999:36-62.
BOOK REVIEWS

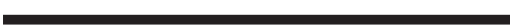

Comprehensive Clinical Hepatology. Edited by JG O'Grady, JR Lake, PD Howdell (illustrated; £129.00). UK: Harcourt Publishers, 2000. ISBN 0-7234-3106-X.

The rapid and exciting developments in hepatology in recent years make an innovative and comprehensive textbook of clinical hepatology very welcome. The editors, who are themselves international authorities in the field, have assembled an impressive array of multinational hepatological talent to compile their comprehensive textbook of clinical hepatology. It is a pleasure to read a textbook where each of the chapters is written by an authority in the field. One problem of such multiauthor books can be the often jarring changes in style between different contributors, but the editors of this book are to be congratulated in assimilating a diverse group of writers and editing their work into a uniform and very readable style. The other aspect of this book, which impresses you immediately, is the clarity of the presentation, particularly the figures. The book is beautifully laid out and the figures are superb. If the publishers made these figures available on a CD-ROM, I am sure that all of us who lecture on liver disease would snap them up immediately. The surgical chapters are particularly impressive, not only for the quality of the figures and the straightforward explanation of the techniques, but also because they have been included in a textbook of hepatology. This is evidence of the multidisciplinary approach, which is such an important part of treating patients with liver disease. Given the interest of the editors it is not surprising that liver transplantation is given the prominence it deserves in a textbook of hepatology and the subject is covered comprehensively from surgical techniques and patient selection through to the excellent chapter from Geoff McCaughan on immunology and immunosuppression. Other highlights include the superb chapter by Fan and Steer on cell biology, where again the quality of the illustrations makes it a pleasure as well as an education to read, and a welcome chapter on the liver in the critically ill, a common but often neglected clinical problem.

So are there any criticisms? I have a few complaints about areas that in my opinion have been neglected. The chapters are organised by individual diseases, which means that some of the more general processes are not covered in full. For instance, it would have added to the book to have a chapter on fibrogenesis and the development of cirrhosis; two other areas that probably warrant a chapter of their own are radiology, particularly with the increasing capabilities of interventional radiologists, and the role and interpretation of liver biopsy. As far as clinical areas are concerned, I could find no mention of liver disease in bone marrow transplantation, a difficult area which would benefit from being covered in a book such as this. A minor quibble is the indexing which I would revise for the next addition. There are several omissions; for example, benign intrahepatic cholestasis and veno-occlusive disease are both discussed in the text but not listed in the 